tones and silvery trill make up for that lack.

It is indeed pleasant for Canadians to have this bond of union with Europe, and especially with England, the land of Shakespeare. In the more than six hundred references to birds in Shakespeare's plays, a score refer to the skylark. In Cymbeline, the delightful song "Hark, Hark! the Lark at Heaven's gate sings" has enchanted thousands of listeners, though Imogen herself vouchsafed no notice. In Henry V it sounds so natural and commonplace to have the Dauphin say: "from the rising of the lark to the lodging of the lamb."

As a small boy Shakespeare noted, as have all who know larks, that the first sound as he rises is loud and rather harsh, so in King Lear we read "The shrill-gorged lark so far cannot be seen or heard." In The Merchant of Venice, Portia says "the crow doth sing as sweetly as the lark when neither is attended," and that humorous statement none can gainsay.

Bird-song seems to have been in every fibre of the man. In $A$ Midsummer Night's Dream Helena says enviously to Hermia "your tongue's sweet air is more tuneable than lark to shepherd's ear," and the tragic note is struck in Richard II with:
Down Court! Down King!

For night owls shriek where moun ing larks should sing.

Again, a different note when Troil says to Cressida "the busy day, wake by the lark, hath roused the ribal crows."

Then in that touching scene Romeo and Juliet where Juliet trif to persuade Romeo that he is lister ing to the nightingale, he respond "It was the lark, the herald of th morn - no nightingale - night candles are burnt out and jocund de stands tip-toe on the misty mounta. tops.'

In the fourteenth stanza of $T r$ Passionate Pilgrim, as the frettir sleepless man listens to Philomel the nightingale, singing, he moanin: ly wishes "her lays were tuned lit the lark; for she doth welcome da: light with her ditty, and drives aw: dark dismal-dreaming night."

So all through his life the sme town boy recalls the birds he kne and loved in his youth. These a: only a $f \in w$ of the hundreds of refe ences showing an accurate knowled! of those that came under Shak speare's own observation, but th encourage one to take greater noti of those within one's own neighbo hood.

\title{
Besant - A Memory
}

\section{By ROSE McLAUGHLIN, Indian Head}

Betiveen Caron and Mortlach, Saskatchewan, there lies a scrubby sitretch of pasture and wasteland, its choppy hillsides pitted with the sandy scars of eroding winds, and its brushy flats threaded by a trickle which swells into a flood in years of bountiful rainfall. Traversed today by the mainline of the C.N.R., and by Trans-Canada highways and skyways, it was likewise in the stream of man's earliest migrations, for this is the region known as Besant, happy hunting ground of our archaeologists.

In the Blue Jay I read of their comings and goings in Besant, and wonder nostalgically if their finds include a sheltered glade carpeted with lawn grass and tiny pink and white clover. Do they have any scientific theory for its presence in that wild anci lonely spot? And do they spread their picnic cloth there on the gentle bank by the stream edge, as we have done so often summers past?

To dwellers of the plains, west Mcose Jaw, Besant was a place enchantment where one might fi again all the flora and fauna lost the change-cover to cultivation. De sometimes strayed into the open, a] little gray ground squirrels nibbl furtively at our tossed crusts. Há thorn, chokecherry, and saskato perfumed the air in spring, and su fused it with color in the fall. $T$ profusion of wildflowers was divid by this frustrated naturalist into ty classes: the common ones that ever one knows and the strangers that one knows.

Nowhere have I seen the brev: of cur prairie summer so emphasiz as at Besant. In July when the queens of the summer - lily, ro 
aillardia, and harebell-are at their eak, one could still find late blosoms of violet and white anemone in he long grass under the trees, while the same time goldenrod and sunlower were budding along the sunny ailroad grade.

Besant had other attractions too. the creek, twisting dankly under a lose canopy of willow, widened into wimming hole at one point, at anther, just beside the vellvety lawn rickle where the wee ones splashed. xxcursions along its bank yielded a andful of wild strawberries, a hatul of raspberries or saskatoons. Girls athered wild flowers along the rade, and little boys loved to roam he pitchy hills-but woe to the bare foot that came down on a cactus! There was, too, an open pasture where an impromptu ball diamond could be laid cut.

Here, I remember, in the dry, dry summer of 1948 a Sunday School picnic lunch lay spread, to its last detail, when a sudden splash of rain sent us running to the cars. Late that same summer we came to Besant once again for a cornfeed which almost didn't come off, because the cooks arrived with two coffee pots and no kettle for the corn. However, we cooked it in relays, packed upright in the larger coffiee pot, and had a wonderful time. Food, fire, and friends by a sheltered stream still work their ancient, elemental spell.

\section{Seen by a Seer}

\section{By J. BOSWELL BELCHER, Dilke, Sask.}

This time I have three items to eport which I thought were of some nterest.

Considering the name of our magaine, I should probably first report he appearance of two Blue Jays in ur shelter belt early in October of his year. They were the first I had ver seen, and the only ones I have eard of in our district.

The second incident occurred beore the first, on a Saturday afiteroon early in August. I had stopped utting grain in order to make an djustment on the swather, and I eard a most unusual chirping about he. Although there were many rickets in the fields, I thought it as a raither strange chirping for a ricket. However, I knew it wasn't hy machine and surely wasn't interering with its operation, so I gave no more thought and went about yy swathing. Monday when I stoped in the field the strange chirping yas there again. It sounded so much ke house sparrows that I glanced bout to check, but no bird was in ght. As I walked around the wather I noticed the sound on the ther side of me so I became curious nd traced the sound right to its purce, which seemed to be the heavy ipe frame at the back of the swather. hen I realized I had a family of ouse sparrows with me which could ot be reached without disassembling art of the machine. Each morning after that I noticed the parents feeding the young as the swather sat in the yard. They had found the swather, though it was left standing at night some distance from where it had been when the nest was built. One day at noon I even noticed Mr. Sparrow sitting on the post with his beak full of insects waiting for me to come home. I was never home at night till after dark, so the little birds must have gone quite hungry. Fortunately for the sparrows, however, the crop was not maturing too fast and I only swathed during the afternoons most days for the first week. The sparrows kept on chirping as they rode around and around the fields until near the end of the week when they had cut over 200 acres and decided to leave their home on wheels.

Oddly the third incident occurred first. It was shortly after the middle of July and Dad was cutting hay in a very rough slough about a mile and a half from home. He was quite surprised when a little fawn, by its size and actions obviously only days old, scrambled up from behind the cutter bar and scampered into the wheat on his wobbly little legs. Quite aware of the probability of other fawns boing near at hand. Dad thought he'd keep a more careful watch and not have that happen again. But a few rounds later he ran the cutter bar over another tiny fawn, again so well hidden in a 